\title{
SELF EFFICACY OF FAMILY PLANNING ACCEPTORS IN SELECTING CONTRACEPTION METHODS
}

\author{
Elis, Kamsatun \\ Poltekkes Kemenkes Bandung, Indonesia \\ Correspondence: kamsatun70@gmail.com
}

\begin{abstract}
The behavior of family planning acceptors in choosing the contraception methods was influenced by several factors. Banduras' theory stated that the cognitive processes including making a decision, having beliefs, or appreciating self-abilities were a consideration in understanding individuals' capabilities to deal with certain tasks. The purpose of this study was to determine the relationship between self-efficacy and the selection of contraception methods. This research applied the colerational design with a crosssectional approach. Independent variable was the level of Self-efficacy and the dependent variable was the choice of contraception methods. The population in this study were all fertile age couples (15-49 years) who were part of family planning acceptors in the Kopo sub-district Bandung Regency. The samples were 70 people that were chosen using cluster sampling techniques. Instruments of this study were the self-efficacy scale based on Bandura (1997) aspect of self-efficacy in Ghufron (2010) and the modification scale of General Self-Efficacy (GSE) from Schwarzer and Jerusalem (1995). According to Schwarzer et al (2009) states that the GSE scale is a unidimensional scale where the GSE scale of 12 items is a unity of aspects of magnitude, strength, and generality. Analysis using the Chi-Square test. There was a relationship between self-efficacy and contraception selection with p-value 0,031. Family planning counseling with health providers would motivate acceptors. Family planning acceptors improved self-efficacy so that family planning acceptors would be confident with the choice of contraception used and avoid the risk of harmful pregnancy.
\end{abstract}

Keywords: Self-efficacy, Family Planning Participants

\section{INTRODUCTION}

The biggest problem in Indonesia is increasing in population growth rates every year.

The estimated population of Indonesia in 2014 were 252.124 .458 inhabitants. The increase of the Indonesian population is relatively fast, it is necessary to regulate or limit the number of births so that population would be controlled and increasing population welfare. The highest number of Indonesian population was the Province of West Java: 46,300,543 people, (MOH 2014).

One of the government's actions to control the population was by implementing a family planning (KB) program for couples in reproductive ages (PUS). Types of contraception included a drug (medications) or tools to prevent pregnancy. There are 
two types of contraception, namely the Long-acting reversible contraception method (MKJP) and the Short-acting reversible contraception method (Non-MKJP) (BKKBN, 2011).

The contraception methods that use in Indonesia is dominated by short-term contraception methods. According to Riskesdas (2013), the majority of Indonesian couples in childbearing chose the injection methods (34.3\%), then the injection method is the largest contributors to the Non-MKJP group. Until June 2014 the number of family planning acceptors in the region of West Java reached $73.74 \%$ of reproductive couples. However, the user of MKJP was low (22.5\%), while Non-MKJP was $77.5 \%$ (BKKBN JABAR, 2014). In Bandung district, the proportion of PUS who participated in family planning programs were 552,482 couples which consisted of an-MKJP (63\%) and MKJP was $37 \%$.

Laksmi (2009) said that a spouse's support has an influence on wife's decisionmaking in selecting the contraception method. In addition, Radita (2009) stated that age, wife's factors, the number of children, and the level of education affected contraception choices. Furthermore, Desy (2010) argued factors that influence women in selecting the contraception method were age, parity/ number of childbirth, reproductive purpose, other people influence, personal factors, health condition, economic, and the effectiveness of contraception methods.

Some people prefer Non-MKJP methods even though they do not want to have an additional child, on the other side the Non-MKJP aims to manage pregnancy time or only for the temporary period (INFODATIN, 2014). Those behavior describe that some people have not been able to choose contraception appropriately. The impact of the inappropriate selection of contraception may risky for young and old pregnancy. 
Health workers have provided counseling and information about contraception methods comprehensively, however, the family planning acceptors' decision sometimes did not match with the aim of contraceptive methods. Maybe, there are other factors who influence in choosing the contraception methods such as the belief factor. Bandura's $t$ theory stated that the cognitive processes including making a decision, having beliefs, or appreciating self-abilities were considerations in understanding individuals' capabilities to deal with certain tasks, those called as self-efficacy.

The preliminary study found the percentage of family planning acceptors consisted of $16.6 \%$ of MKJP dan 83.4\% of Non-MKJP on March 25, 2017, in the Kopo Public Health Center, Kutawaringin sub-district. In addition, interviews found that several acceptors shared their reason for choosing Non-MKJP methods including afraid of the side effects of MKJP methods and also the possible failure of these methods. It can be concluded that the majority of Non-MKJP contraception users do not understand their ability to decide the choices and they may less confidence in their decision related to contraception methods choice. The purpose of this study aim was to determine the relationship between self-efficacy and the selection of contraception methods.

\section{METHODS}

This study was a correlation study with a cross-sectional approach. The independent variable was the level of Self-efficacy and the dependent variable is the choice of contraception. The population was coupled in reproductive age (15-49 years), who participated in family planning programs in the Kopo PHC. The population was 1239 respondents. The sample was counted using the proportion estimation formula (Nursalam,2014): 


$$
\begin{gathered}
\mathrm{n}=(\mathrm{Z} 1-\alpha / 2)^{2} \cdot \mathrm{PQ} \\
\mathrm{d}^{2} \\
\mathrm{n}=(1.96)^{2} .0 .75(1-0.75) \\
(0,10)^{2} \\
\mathrm{n}=70
\end{gathered}
$$

$\mathrm{n}=$ Sample

$\mathrm{Z} 1-\alpha / 2=$ value of table $\mathrm{Z}$ for trust $95 \%(1,96)$

$\mathrm{P}=$ Estimate the proportion of active family planning acceptors in Bandung (75\%)

$\mathrm{Q}=1-\mathrm{P}$

$\mathrm{d}=$ The error rate $(0.10)$

Based on the calculation, the number of samples was 70 people. In selecting acceptors, the researchers used Cluster Sampling technique. The setting of this study was divided into 3 community areas (RW) including RW 13, RW 05, and RW 06 areas of the PHC Kopo. The data collection was held in May 2017. The data were collected using an instrument that modified from self-efficacy instruments of Bandura (1997) and Schwarzer and Jerusalem (1995). There were 12 items of questions related to magnitude, strength, and generality aspects. The researchers modified Likert scale, the original scale was five-point ranges, then modified into four-point scales range such as SS (strongly agree), S (agree), TS (disagree) and STS (strongly disagree). The point is calculated by the proportion of items with categories $S S=4$ points, $S=3$ points, $T S=2$ points, STS = 1 point. The self-efficacy divided into two categories: the low category when the score less than the median, and the high category when the score higher than the median: 42. Researchers did the test validity of the instrument, this test involved 20 acceptors, 12 questions were valid with $\mathrm{r}$ table value 0.379 , and the validity score was 0.45 to 0.831 . The valid questions have covered the indicator of self-efficacy aspects which are strength, generality and dimension level. 
The data were analyzed using univariate and bivariate analysis. The univariate analysis presented findings into two categories of high and low self-efficacy, and the bivariate analysis carried out a statistical test which is the Chi-Square test. This test was applicable for this study because this study aims to examine the relationship between two variables. This study also presented the characteristic respondents including age, education and employment status. The data were analyzed using a computerized program SPSS 20.

Researchers conduct research by emphasizing the ethical issues of research according to Notoatmodjo (2014) including Inform Consent, Anonymity, and Confidentiality. The researcher asked respondents' approval. The respondents read and signed the informed consent form voluntary. The questionnaire form was anonym and only researchers who have access to respondents' answer. The data located in a safe place.

\section{RESULTS}

Three tables present in this section including characteristic respondents, the level of self-efficacy, types of contraception, and the relationship between self-affection and the behavior in selecting contraception methods.

\section{Characteristic of respondents}

Table 1 Characteristic Respondents $(n=70)$

\begin{tabular}{lcc}
\hline \multicolumn{1}{c}{ Characteristic } & Frequency & Percentage \\
\hline Age & & \\
a. 20-35 year (Early Adult) & 24 & $34,3 \%$ \\
b. 36-45 year (Late Adult) & 35 & $50 \%$ \\
c. 46-50 year (Pre Elderly) & 11 & $15,7 \%$ \\
\hline Total & 70 & $100 \%$ \\
\hline Education & & \\
a. Elementary school & 14 & $20 \%$ \\
b. Junior high school & 20 & $38,6 \%$ \\
c. Senior high school & 36 & $51,4 \%$ \\
\hline
\end{tabular}




\begin{tabular}{lcc}
\hline Total & 70 & $100 \%$ \\
\hline Work status & & \\
a. Employee & 2 & $2,9 \%$ \\
b. Entrepreneur & 1 & $1,4 \%$ \\
c. Teacher & 1 & $1,4 \%$ \\
d. Housewife & 66 & $94,3 \%$ \\
\hline Total & 70 & $100 \%$ \\
\hline
\end{tabular}

A half of the respondents $(n=35)$ are 36-45 years (late adult). More than half of respondents attended high school education $(n=36)$ and almost all respondents were a housewife with the number of 66 people $(94.3 \%)$.

\section{The level of self-efficacy}

Table 2 Frequency Distribution of The Self-Efficacy Level in Family Planning Acceptors (n=70)

\begin{tabular}{ccc}
\hline Self-efficacy & Frequency & Percentage \\
\hline High & 36 & $51,4 \%$ \\
Low & 34 & $48,6 \%$ \\
\hline Total & 70 & $100 \%$ \\
\hline
\end{tabular}

The majority of acceptors had a high self-efficacy level with a total of 36 people $(51.4 \%)$

Types of contraception methods selected by acceptors

Table 3 Frequency Distribution of Contraception Types that Selected by Acceptors $(\mathbf{n}=\mathbf{7 0})$

\begin{tabular}{ccc}
\hline Contraception & Frequency & Percentage \\
\hline MKJP & 35 & $50 \%$ \\
Non-MKJP & 35 & $50 \%$ \\
\hline Total & 70 & $100 \%$ \\
\hline
\end{tabular}

Table 3 presents that the percentage of respondents who choose MKJP and NonMKJP were the same (50\%). 


\section{Correlation between self-efficacy and contraception method choices}

Table 4 The relationship between of Self-Efficacy and Contraception Method Selection $(\mathbf{n}=\mathbf{7 0})$

\begin{tabular}{ccccc}
\hline \multirow{2}{*}{ Category } & \multicolumn{2}{c}{ Type of Contraception } & \multirow{2}{*}{ Total } & \multirow{2}{*}{ P Value } \\
& MKJP & Non-MKJP & & \\
\multirow{2}{*}{ High } & 23 & 13 & 36 & \\
& $63,9 \%$ & $36,1 \%$ & $100 \%$ & \\
Low & 12 & 22 & 34 & 0,031 \\
& $35,3 \%$ & $64,7 \%$ & $100 \%$ & \\
\multirow{2}{*}{ Total } & 35 & 35 & 70 & \\
& $50 \%$ & $50 \%$ & $100 \%$ & \\
\hline
\end{tabular}

The results of the research found the p-value 0.031 smaller than $\alpha=0.05$ indicated that there was a relationship between self-efficacy and the choice of contraception.

\section{DISCUSSION}

\section{Description of Self Efficacy rate on family planning acceptors}

Bandura (1997) defines self-efficacy as one's belief in its ability to regulate and carry out actions to achieve the stated goals, and strive to assess levels and strengths in all activities and contexts. Factors that may affect the level of self-efficacy include gender, education, age, and experience. The characteristics of family planning acceptors were a half of them 36-45 years old. The respondents were mostly KB used MKJP contraception. Bandura (1997) describes that self-efficacy formed through the social learning process. The older individuals tend to have a high level of self-efficacy because they had more experience in overcoming life problems.

More than a half of respondents attended senior high school $\mathrm{n}=36(51.4 \%)$. Bandura (1997) argued that self-efficacy formed through the learning process that can be accepted by individuals who have high the level of formal education. Individuals who have a high level of formal education commonly they have a high level of self- 
efficacy. It might be because of basically they learned and received more formal education, in addition, they had more opportunities to learn problem-solving methods and overcoming their life problems.

This study showed that more than a half of the respondents 36 people $(51.4 \%)$ had high self-efficacy rates and 34 people $(48.6 \%)$ had low self-efficacy. Self-efficacy would be formed from various sources of age and education. In this study, almost half of respondents aged 36-45 years (late adult) with the most recent education were high school. So it can be a factor that influences the level of self-efficacy in family planning acceptors.

\section{The relationship between self-efficacy and the selection of contraception methods}

Factors that influence the selection of contraception include socio-demography, socio-psychology and health services. One of the socio-psychological factors that influence the selection of contraception is belief. Another factor is the ability in overcoming a problem that influences decision making, Bandura's theory (1997) called self-efficacy. In this study, the action was related to choosing contraception methods. The belief factor has a significant influence on personal decision including in choosing contraception methods. When acceptors understand their own expectation of contraception methods, then make a choice, it means they have been able to assess their self-confidence. The results of this study found that there is a relationship between selfefficacy and the choice of contraception methods (p-value 0,031), as 23 respondents of MKJP acceptors had a high level of self-efficacy, while 22 respondents of Non-MKJP acceptors had a low level of self-efficacy. It means MKJP acceptors have high selfconfidence and they were able to assess their ability in making a make decision and 
taking actions to solve a problem. This study finding inline with Kustriyanti's (2012) study stated that there was a significant relationship between couples in reproductive ages' (PUS) self-confidence and the selection of contraception. She found that PUS who participated in family planning programs have a high confidence in choosing contraception methods. Therefore PUS who were family planning acceptors should improve their confidence in order to make a decision. Health professionals including nurses should motivate PUS in a positive way related to selecting contraception methods.

There were other factors that may influence the selection of contraception which is age and education. Anita's (2014) study found there was a significant relationship between age and education in contraception choices. Women aged 30 years old and more had a good understanding of MKPJ methods. The characteristics of respondents might be affected by the level of their self-efficacy. This self-efficacy is needed by family planning acceptors to improve their self-belief when they choingose MKPJ methods. The cases of pregnancy with high-risk conditions may also part of the inappropriate decision of contraception methods. The high level of self-efficacy is needed to minimize any risks that would be impacted women's health. Health professionals should motivate accepts and provide clear information on family planning to prevent withdraw from family planning programs or changes their choices frequently. The high self-esteem is very important for acceptors in choosing contraception methods. A high self-efficacy helped acceptors in establishing their choices and may influence their success in family planning programs. It is important for women with high parity to choose MKPJ to reduce risk conditions. There is a need to improve women's selfefficacy especially who over 35 years old and had children 2 or more to choose MKPJ. 
The sources of self-efficacy can be obtained from various sources. The acceptors of family planning should obtain support to improve their self-efficacy. Bandura's theory (1997) stated that the self-efficacy sources would be information about good experiences or a success story, that information would enhance their ability in making a decision. Improving acceptors' self-efficacy would influence their choice related to MKPJ as this method is more effective and efficient to prevent pregnancy. The level of self-efficacy had influenced an individual in taking a decision that has various consequences. Therefore, it is important to motivate acceptors related to their selfefficacy in choosing contraception methods. A high self-efficacy may influence acceptors in choosing MKPJ. The MKPJ is effective to prevent any side effects and high risks in reproductive couples, as the main purpose of family planning programs is that contraception methods should effective and safe for acceptors in the long-term period.

\section{CONCLUSION}

Almost half of the respondents in the Kopo PHC had a high level of self-efficacy. A half of respondents chose MKPJ. There is a relationship between self-efficacy and contraception methods selection with p-value 0,031

The PHC should improve their services especially counseling services for couples in reproductive ages. Health providers in the PHC should motivate family planning acceptors to improve their self-efficacy, as a result, they would be satisfied with their choices related to contraception methods.

\section{REFERENCES}


Agus,Riyanto. (2011). Buku Ajar Metodologi Penelitian. Jakarta: EGC

Anita Lontaan, Kusmiyati, dan Robin Dompas. 2014. Faktor-Faktor Yang Berhubungan Dengan Pemilihan Kontrasepsi Pasangan Usia Subur Di Puskesmas Damau Kabupaten Talaud Volume 2 Nomor 1. Jurnal Ilmiah Bidan. Politeknik Kesehatan Kemenkes Manado.

Arikunto, Suharsini. (2013). Prosedur Penelitian Suatu Pendekatan Praktek. Jakarta: PT Rineka Cipta

Charis Cristiani, Cristine, dan Bambang. 2014. Faktor-Faktor yang mempengaruhi Pemakaian Metode Kotrasepsi Jangka Panjang (MKJP) Provinsi Jawa Tengah. Serat Acitya-Jural Ilmiah. UNTAG Semarang.

Depkes RI.(2014). Profil Kesehatan Indonesia 2014. Jakarta. http://www.depkes. go.id.

Fianelia, Rainy A. (2012). Factor-Faktor Yang Berhubungan Dengan Penggunaan MKJP Di Wilayah Kerja Puskesmas Pancoran Mas Kota Depok. Skripsi. Fakultas Kesehatan Masyarakat Universitas Indonesiahttp://lib.ui.ac.id/file?file=digital/20319551-S-Maretha\%20Hasian.pdf.

Fitria Wulansari, Heni dan Suhariyati. 2014. Persepsi Ibu Tentang Penggunaan Alat Kontrasepsi AKDR di Desa Manunggal Kecamatan Ngusikan Kabupaten Jombang. STIKES Pemkab Jombang.

Ghufron, M. Nurdan Rini Risnawati. (2010). Teori-teori Psikologi. Jogyakarta: ArRuzz Media

Hamzah, Ali dkk. (2017). Panduan Penyusunan Karya Tulis Ilmiah (KTI). Bandung: Poltekkes Kemenkes Bandung Jurusan Keperawatan Bandung

Handayani, Sri.(2010). Buku Ajar Pelayanan Keluarga Berencana. Yogyakarta: Pustaka Rihama.

Handayani, Desy. (2010). Faktor-Faktor Yang Mempengaruhi Ibu DalamPengambilan Keputusan Memilih Alat Kontrasepsi Dalam Rahim (AKDR) Di Wilayah Bidan Praktik Swasta Titik Sri Suparti Boyolali. ISSN 2087-5002

Hidayat, A. Aziz Alimul. (2007). Metode Penelitian dan Teknik Analisis Data. Jakarta: Salemba Medika

Irianto, Koes. (2014). Pelayanan Keluarga Berencana. Bandung: Alfhabeta

Isma Ghinta Awali, Iroma, dan Mutiarawati. 2013. Faktor-Faktor yang Berhubugan dengan Perilaku Pemilihan Jenis Kontrasepsi Hormoal di Desa Kemurang Wetan Kecamatan Tanjung Kabupaten Brebes. Politeknik Harapan Bersama Tegal. Diakses tanggal 28 Juni 2017 
Izzah, Shohifatul. (2012).Perbedaan Tingkat Self-Efficacy Antara Mahasiswa Fakultas Psikologi Dan Sains Dan Teknologi UIN Malang, Skripsi, Fakultas Psikologi Universitas Islam Negeri Malang http://etheses.uin-malang.ac.id/2231/1/08410092_Pendahuluan.pdfDiakses pada bulan Maret 2017

Kustriyanti dan Priharyanti Wulandari. 2012. Faktor-Faktor yang Berhubungan dengan Pemilihan Alat Kontrasepsi pada Wanita Usia Subur di Puskesmas Ngesrep Kelurahan Ngesrep Kecamatan Banyumanik Semarang. STIKES Widya Husada Semarang.

Lusiana, Novita dkk. (2015). Metodologi Penelitian Kebidanan. Yogyakarta: Deepublish.

Laksmi, Indira. (2009). Faktor-Faktor yang Mempengaruhi Pemilihan Jenis Kontrasepsi yang digunakan pada Keluarga Miskin. Karya Tulis Ilmiah. Fakultas Kedokteran Universitas Semarang http://eprints.undip.ac.id/18903/Diakses pada bulan Maret 2017

Notoatmodjo, Soekidjo. (2014). Metodologi Penelitian Kesehatan. Jakarta: Rineka Cipta.

Notoatmodjo, Soekidjo. (2007). Promosi Ilmu Kesehatan dan Perilaku. Jakarta: Rineka Cipta.

Nugroho, Taufan dan Utama, Bobby Indra.(2014). Masalah Kesehatan Reproduksi Wanita. Nuha Medika. Yogyakarta

Nursalam. (2015). Metodologi Penelitian Ilmu Keperawatan: Pendekatan Praktis Edisi 4. Jakarta: Salemba Medika

Nursalam. (2015). Metodologi Penelitian Ilmu Keperawatan: Pendekatan Praktis Edisi 4. Jakarta: Salemba Medika

Puspitasari, Nunik. (2008). Metode Kontrasepsi. Surabaya: Departemen Biostatistika Dan Kependudukan Fakultas Kesehatan Masyarakat Universitas Airlangga

Radita Kusumaningrum. (2009). Faktor-Faktor Yang Mempengaruhi Pemilihan Jenis Kontrasepsi yang Digunakan Pada Pasangan Usia Subur. Semarang: UNDIP. http://eprints.undip.ac.id/19194/1/Radita_Kusumaningrum.pdf. September 2010.

Sawarjana, I Ketut. (2015). Metodologi Penelitian Kesehatan: tuntunan praktis pembuatan proposal penelitian edisi revisi. Bali: CV Andi OFFSET

Sugiyono. (2010). Metode Penelitian Pendidikan Pendekatan Kuantitatif, Kualitatif, Dan $R \& D$. Bandung: Alfabeta

Sugiyono. (2013). Metode Penelitian Pendidikan Pendekatan Kuantitatif, Kualitatif, Dan $R \& D$. Bandung: Alfabeta 
Elis: Self Efficacy of Family Planning Acceptors

Hastono, Susanto P. (2006). Analisis Data. Universitas Indonesia

Wiknjosastro, Hanifa. (2007). Ilmu Kebidanan. Jakarta: Yayasan Bina Pustaka Sarwono Prawirohardjo www.bkkbn.go.id

----. Informasi dan Pusat Data Keluarga Berencana kemenkes RI (2014). 